\title{
DYNAMIC STUDIES OF NITROPHENOLS SORPTION ON PERFIL IN A FIXED-BED COLUMN
}

\author{
Zvezdelina Yaneva $^{1}$, Mirko Marinkovski ${ }^{2}$, Liljana Markovska ${ }^{2}$, Vera Meshko $^{2}$, Bogdana Koumanova $^{1}$ \\ ${ }^{1}$ Department of Chemical Engineering, University of Chemical Technology and Metallurgy, \\ 8 Kliment Ohridski, Sofia, 1756 Bulgaria \\ ${ }^{2}$ Faculty of Technology and Metallurgy, "SS. Cyril and Methodius" University, \\ Ruger Bosković 16, MK-1000 Skopje, Republic of Macedonia \\ bkk@uctm.edu
}

\begin{abstract}
The adsorption of two substituted nitrophenols, namely 4-nitrophenol (4-NP) and 2,4-dinitrophenol (2,4DNP), from aqueous solutions onto perfil was studied using a fixed bed column. The theoretical solid diffusion control (SDC) model describing single solute adsorption in a fixed bed based on the Linear Driving Force (LDF) kinetic model was successfully applied to the investigated systems. The model parameters of solid diffusion coefficient, $D_{\mathrm{S}}$, axial dispersion coefficient, $D_{\mathrm{L}}$, and external mass transfer coefficient, $k_{\mathrm{f}}$, for the investigated systems were estimated by the means of a best fit approach. Some deviations were found between the predicted and the experimental data which reflect the fact that the assumptions of the model were not quite fulfilled for these experiments. It is necessary to adjust the values of the solid diffusion coefficient, the axial dispersion coefficient and the external mass transfer coefficient in order to obtain a satisfactory agreement between the simulated and the experimental breakthrough curves. A Biot number was used as an indicator for the intarparticle diffusion. The Biot number was found to decrease with the increase of bed depth, indicating that the film resistance increased or the intraparticle diffusion resistance decreased.
\end{abstract}

Key words: adsorption; nitrophenols; perfil; fixed bed modeling; solid diffusion control

\section{ДИНАМИЧКИ СТУДИИ ЗА АТСОРПЦИЈАТА НА НИТРОФЕНОЛИ ВРЗ ПЕРФИЛ ВО КОЛОНА СО ФИКСЕН СЛОЈ}

\begin{abstract}
Испитувана е атсорпцијата на два супституирани нитрофеноли, 4-нитрофенол (4-NP) и 2,4-динитрофенол $(2,4-\mathrm{DNP})$ врз перфил во колона со фиксен слој на атсорбент. Врз испитуваните системи е применет теоретскиот модел на дифузија во цврсто (SDC), при што за опишување на кинетиката на атсорпција е употребена линеарна движечка сила (LDF). Пресметани се моделните параметри: коефициентот на дифузија во цврсто, $D_{\mathrm{S}}$, коефициентот на аксијална дифузија, $D_{\mathrm{L}}$, и коефициентот на пренос на маса во надворешниот филм, $k_{\mathrm{f}}$, преку фитување на експерименталните и теоретските податоци. Отстапувањата на експерименталните податоци од теоретските криви наведуваат на заклучок дека претпоставките во моделот не се целосно исполнети во овие експерименти. Потребно е приспособување на вредностите на коефициентот на дифузија во цврсто, коефициентот на аксијална дифузија и коефициентот на пренос на маса во надворешниот филм, за да се добие задоволително совпаѓање на експерименталните податоци со симулираните теоретски криви. Бројот на Биот е користен како индикатор за уделот на внатрешната дифузија. Беше покажано дека бројот на Биот се намалува со зголемување на висината на слојот во колоната, што значи дека отпорот во цврстиот атсорбент се намалува, а расте отпорот во надворешниот филм.
\end{abstract}

Клучни зборови: атсорпција; нитрофеноли; перфил; моделирање на колона со фиксен слој; дифузија во цврсто

\section{INTRODUCTION}

Nitrophenols are pollutants of great concern as they are toxic and some of them are known or suspected to be carcinogenic when present at elevated levels in the environment. They are contained in many industrial effluents such as those 
from oil refineries, plastics, textile, rubber processing plants, pesticide production, etc. [1].

A great number of publications demonstrate the effective adsorption of nitrophenols on low cost materials such as natural minerals (bentonite, perlite, zeolites) [2-6], polymers [7-9], waste products $[10,11]$, biomaterials [12], as well as the applicability of numerous mathematical models for correlation of the experimental equilibrium, kinetic and dynamic data. The goal of this work is to elucidate the mechanism of the process and to outline the main rate-limiting stages.

Adsorption dynamics acquaintance and modeling are essential because they provide valuable information on some practical aspects such as sorbent capacity and prediction of the time necessary for the effective operation of a fixed-bed column. At the same time they assist in making more detailed conclusions about the mechanism of the process. Some of the mathematical correlations for adsorption in fixed-bed columns are based on the assumption of one mass transfer resistance, while others consider the influence of more mechanisms, as well as the effect of axial dispersion. Many researchers apply the Bed Depth Service Model (BDST) and its modifications to account for the influence of some system parameters (flow rate, initial sorbate concentration) on the breakthrough curve progress. The BDST model is widely applied for description of phenols, dyes adsorption on low cost alternative sorbents (rice husk, hair) $[13,14]$, modified zeolites [15], etc. The dynamic adsorption behavior of phenols on a resin was explained by means of an external mass transfer resistance model [16]. The widely applied in literature Thomas model also accepts this hypotheses $[17,18]$. Other group of empirical equations applied for phenols and dyes adsorption, adopt solid phase mass transfer resistance. Additional assumptions are the Langmuir isotherm, constant pattern adsorption front, etc. [3, 19].

The two resistance models and those accounting for axial dispersion give more explicit information for the adsorption behavior of the systems in fixed-bed columns [20-22]. Lin and Wang correlate the experimental data of phenolic wastewater adsorption on a resin by a model incorporating external mass transfer resistance and axial dispersion [23]. Few years later Vazquez et al. successfully described the fixed-bed operation behavior of phenol adsorption on Pinus Pinaster bark using the same empirical correlations [24]. The investi- gations of Wolborska et al. demonstrate the high accuracy of a model based on the latter two assumptions, as well as on a constant fluid flow rate and constant values of the kinetic coefficients in the low-concentration region, for the initial breakthrough curve section when adsorbing phenol, nitrophenol, chlorophenols and benzoic acid on activated carbon [25] and dyes on activated montmorillonite, cedar sawdust and crushed brick [20, 21]. A theoretical two resistance film-pore diffusion model (FPD) was successfully applied to predict the concentration profiles of metal ion adsorption on coir for various system variables, including initial sorbate concentration, flow rate and bed depth [26]. These models tend to differ in their description of the adsorption mechanism occurring within the adsorbent particle, assuming either pore diffusion within the liquid-phase or solid diffusion within the solid-phase. In this study a film-solid diffusion model is applied to investigate the mass transfer process in a fixed bed column. This model was employed to describe the adsorption of 4nitrophenol and 2,4-dinitrophenol onto perfil in fixed bed column.

\section{MATHEMATICAL MODEL}

The dynamics of a fixed bed is described by a set of convection diffusion equations, coupled with source terms due to adsorption and diffusion inside the adsorbent particles. The prediction of the breakthrough curves is based on correctly formulating the mathematical model for a fixed bed adsorber $[19,27,28]$. The system considered here is an isothermal adsorption column packed with porous adsorbent. At time zero, a step change in the concentration of an adsorbate was introduced to the flowing stream. The adsorption column was subjected to axial dispersion, external film mass transfer resistance, and solid diffusion resistance. The following assumptions were made in the analysis:

- No chemical reactions occur in the column.

- The flow pattern is the ideal plug flow.

- Isothermal adsorption of a single component occurs.

- There is negligible concentration gradient in the radial direction.

- The Linear Driving Force (LDF) model was used for presenting the mass transfer into the pellets. 
Under the above assumptions, the governing equations and appropriate initial and boundary conditions can be written as follows:

$$
\begin{gathered}
v \frac{\partial C_{b}}{\partial z}+\frac{\partial C_{b}}{\partial t}+\frac{1-\varepsilon}{\varepsilon} \cdot \frac{d}{d t}\left(\varepsilon_{p} \bar{C}+\bar{q}\right)=D_{L} \cdot \frac{\partial^{2} C_{b}}{\partial z^{2}} \\
t=0, \quad C_{b}=0 \\
z=L, \quad \frac{\partial C_{b}}{\partial z}=0 \\
z=0, \quad C_{i n}=C_{b}-\frac{D_{L}}{v} \cdot \frac{\partial C_{b}}{\partial z}
\end{gathered}
$$

By introducing the dimensionless coordinates:

$$
Y=\frac{z}{L}, \quad \theta=\frac{t \cdot v}{L}
$$

Eqs. (1-4) become

$$
\begin{gathered}
\frac{\partial C_{b}}{\partial Y}+\frac{\partial C_{b}}{\partial \theta}+\frac{1-\varepsilon}{\varepsilon} \cdot \frac{d}{d \theta}\left(\varepsilon_{p} \bar{C}+\bar{q}\right)=\frac{1}{P e} \cdot \frac{\partial^{2} C_{b}}{\partial Y^{2}} \\
\theta=0, \quad C_{b}=0 \\
Y=1, \quad \frac{\partial C_{b}}{\partial Y}=0 \\
Y=0, \quad C_{\text {in }}=C_{b}-\frac{1}{P e} \cdot \frac{\partial C_{b}}{\partial Y}
\end{gathered}
$$

where $P e=\frac{L \cdot v}{D_{L}}$ is the Peclet number.

The third part in Eqs. (1) or (5), the uptake rate expressed on the basis of unit adsorbent volume $[19,28]$ is given by

$$
m=\frac{d}{d t}\left(\varepsilon_{p} \cdot \bar{C}+\bar{q}\right)
$$

In terms of external mass transfer, $m$ may be written as

$$
m=\frac{3 \cdot k_{f}}{R_{p}}\left(C_{b}-C_{S}\right) .
$$

The uptake rate in terms of the intraparticle diffusion can be obtained from the solution of the appropriate intraparticle diffusion equation. The uptake rate expression based on the linear driving force (LDF) model $[19,27]$ for solid diffusion is

$$
m=\frac{15 D_{s}}{R_{p}^{2}}\left(q_{s}-\bar{q}\right)
$$

where $q_{\mathrm{s}}$ and $C_{\mathrm{s}}$ are the adsorbed phase and the fluid phase concentrations, respectively, at the fluid - pellet interface and they are in an equilibrium defined by the Langmuir equation:

$$
q_{s}=\frac{q_{m} \cdot K \cdot C_{s}}{1+K \cdot C_{S}}
$$

or

$$
C_{s}=\frac{q_{s}}{q_{m} \cdot K-K \cdot q_{s}} .
$$

To eliminate the surface concentration from any equation involving the rate of mass transfer (because it cannot be measured by standard techniques, at the steady state), the rate of mass transfer of adsorbate from the bulk fluid to the external pellet surface (Eq. (10)) is equal to the net rate of solid diffusion, which is given by Eq. (11):

$$
\frac{3 k_{f}}{R_{p}}\left(C_{b}-C_{s}\right)=\frac{15 D_{s}}{R_{p}^{2}}\left(q_{s}-\bar{q}\right) .
$$

Substituting Eq. (13) into Eq. (14), one obtains

$$
B i\left(C_{b}-\frac{q_{s}}{q_{m} \cdot K-K \cdot q_{s}}\right)=5\left(q_{s}-\bar{q}\right)
$$

where $B i=\frac{R_{p} \cdot k_{f}}{D_{s}}$ is the Biot number.

Assuming

$$
\frac{d}{d t}\left(\varepsilon_{p} \cdot \bar{C}+\bar{q}\right)=\frac{15 D_{s}}{R_{p}^{2}}\left(q_{s}-\bar{q}\right)
$$

and taking into account that the pore accumulation term is generally small in comparison with the accumulation within the solid $\left(\varepsilon_{P} \bar{c}<<\bar{q}\right)$ one obtains

$$
\frac{d \bar{q}}{d t}=\frac{15 D_{s}}{R_{p}^{2}}\left(q_{s}-\bar{q}\right)
$$

The combination of Eqs. (17) and (15) in dimensionless form yields

$$
\frac{d \bar{q}}{d \theta}=3 B i \cdot T\left(C_{b}-\frac{q_{s}}{q_{m} K-K q_{s}}\right)
$$

where $T=\frac{D_{s} \cdot L}{R_{p}^{2} \cdot v}$. 
Differentiating Eq. (15) with respect to $\theta$ yields

$$
\frac{d q_{s}}{d \theta}=\frac{\frac{d \bar{q}}{d \theta}+\frac{B i}{5} \cdot \frac{d C_{b}}{d \theta}}{1+\frac{B i}{5} \cdot \frac{K}{\left(q_{m} K-K q_{s}\right)^{2}}}
$$

Substituting Eq. (18) into Eq. (19) gives

$$
\frac{d q_{s}}{d \theta}=\frac{3 B i \cdot T\left(C_{b}-\frac{q_{s}}{q_{m} K-K q_{s}}\right)+\frac{B i}{5} \cdot \frac{d C_{b}}{d \theta}}{1+\frac{B i}{5} \cdot \frac{K}{\left(q_{m} K-K q_{s}\right)^{2}}}
$$

Substituting Eq. (18) into Eq. (5) yields

$$
\begin{aligned}
& \frac{\partial C_{b}}{\partial Y}+\frac{\partial C_{b}}{\partial \theta}+3 B i \cdot T \cdot \frac{1-\varepsilon}{\varepsilon} \cdot\left(C_{b}-\frac{q_{s}}{q_{m} K-K q_{S}}\right)= \\
& =\frac{1}{P e} \cdot \frac{\partial^{2} C_{b}}{\partial Y^{2}} .
\end{aligned}
$$

In this paper a computer program based on the mathematical model described by Eqs. (20) and (21) with initial and boundary condition given by Eqs. (6-8) was developed using ISIM software [29] which is capable of solving ordinary and partial differential equations and provides a choice of different integration routines. In this investigation the mathematical model was transformed into a set of first order ordinary differential equations using the finite difference method [29].

\section{MATERIAL AND METHODS}

\section{Adsorbates}

The sorbates used in the experiments are 4nitrophenol (4-NP) and 2,4-dinitrophenol (2,4DNP). Their physical-chemical characteristics are presented in Table 1.

\section{Adsorbent}

The natural mineral perfil used in the experiments was taken from deposits in the southern part of Bulgaria. Its physical and chemical characteristics are given in Table 2 and Table 3
Table 1

Physical-chemical characteristics of 4-NP and 2,4-DNP

\begin{tabular}{lcc}
\hline \hline & 4-NP & 2,4-DNP \\
\hline CAS No & $100-02-7$ & $5-12-85$ \\
Molecular mass, $\mathrm{M}_{\mathrm{m}}, \mathrm{kg} \mathrm{kmol}^{-1}$ & 139.11 & 184.11 \\
Density, $\rho, \mathrm{g} \mathrm{cm}^{-3}$ & $1.270^{*}$ & $1.683^{* *}$ \\
Solubility, g/100 $\mathrm{g} \mathrm{H}_{2} \mathrm{O}$ & 1.7 & 0.6 \\
Boiling temperature, $\mathrm{T}_{\mathrm{b}},{ }^{\circ} \mathrm{C}$ & 279 & 113 \\
Melting temperature, $\mathrm{T}_{\mathrm{m}},{ }^{\circ} \mathrm{C}$ & $113-114$ & 108 \\
pKa & 7.08 & 5.40 \\
Effective molecular diameter, $\mathrm{d}_{\mathrm{m}}, \mathrm{nm}$ & 0.813 & 0.872 \\
Standard maximum wavelength, & & \\
$\quad \lambda_{\max }, \mathrm{nm}$ & 228 & 254 \\
\hline \hline & &
\end{tabular}

Table 2

Physical characteristics of perfil

\begin{tabular}{ccccc}
$\begin{array}{c}\text { Specific } \\
\text { surface area, } \\
a, \mathrm{~m}^{2} \mathrm{~g}^{-1}\end{array}$ & $\begin{array}{c}\text { Total pore } \\
\text { volume, } \\
V_{p}, \mathrm{~cm}^{3} \mathrm{~g}^{-1}\end{array}$ & $\begin{array}{c}\text { Micro- } \\
\text { pores, } \\
\%\end{array}$ & $\begin{array}{c}\text { Transitio- } \\
\text { nal pores, } \\
\%\end{array}$ & $\begin{array}{c}\text { Average particle } \\
\text { diameter, } \\
d_{p}, \mathrm{~mm}\end{array}$ \\
\hline 74.10 & 0.0760 & 1.47 & 98.5 & 3.00 \\
\hline
\end{tabular}

Table 3

Chemical analysis of of perfil

\begin{tabular}{lc}
\hline \hline Content & \% mass. \\
\hline $\mathrm{SiO}_{2}$ & $70-80$ \\
$\mathrm{Al}_{2} \mathrm{O}_{3}$ & $10-15$ \\
$\mathrm{Fe}_{2} \mathrm{O}_{3}$ & $<1.5$ \\
$\mathrm{CaO}$ & $<1.5$ \\
$\mathrm{MgO}$ & $<1.0$ \\
$\mathrm{~K}_{2} \mathrm{O}, \mathrm{Na}_{2} \mathrm{O}$ & $<10$ \\
$\mathrm{TiO}_{2}$ & - \\
Loss at ignition & $<5$ \\
\hline \hline
\end{tabular}

\section{Equilibrium studies}

The equilibrium experiments were accomplished using model solutions of 4-NP, and 2,4DNP in distilled water. The investigations for the mononitrophenol were carried out at a temperature $20 \pm 2{ }^{\circ} \mathrm{C}$ and $\mathrm{pH} 5.6 \pm 0.2$ for $4-\mathrm{NP}$ and for the dinitrophenol at $20 \pm 2{ }^{\circ} \mathrm{C}$ and $\mathrm{pH} 7.4 \pm 0.2$. Solutions were in the concentration range $5-30 \mathrm{mg} \mathrm{dm}^{-3}$ for 4-NP, and 5-30 $\mathrm{mg} \mathrm{dm}^{-3}$ for 2,4-DNP. Known amount of perfil, $0.3 \mathrm{~g}$ for 4-NP and 2,4-DNP equilibrium studies, was added to $100 \mathrm{~cm}^{3}$ of the 
model solutions in screw cap jars. The jars were shaken on a platform shaker. The solute from each jar was filtered. The residual 4-NP and 2,4-DNP concentrations in the liquid phase $\left(C_{\mathrm{e}}\right)$ were determined spectrophotometrically with a SPECORD UV VIS, Carl Zeiss Jena, spectrophotometer. The corresponding values of 4-NP and 2,4-DNP solid phase concentrations $\left(q_{\mathrm{e}}\right)$ were calculated by the mass balance equation

$$
\left(C_{o}-C_{e}\right) V=\left(q_{e}-q_{o}\right) W .
$$

\section{Dynamic Studies}

The dynamic experiments of 4-NP and 2,4DNP adsorption on perfil were conducted in a Plexiglas fixed-bed column with id. $90 \mathrm{~mm}$ and height of $858 \mathrm{~mm}$. The column was supplied with 5 sampling points situated at $100 \mathrm{~mm}$ intervals. A fine mesh and a layer of glass pearls were placed below the adsorbent bed to support it and to ensure uniform distribution of the liquid phase, while another layer of glass pearls was placed above the perfil bed to prevent carry over of sorbent particles. The initial model aqueous solution was fed continuously in an up-flow mode, by a peristaltic pump at a constant flow rate $\left(113 \mathrm{~cm}^{3} \mathrm{~min}^{-1}\right)$, to avoid the formation of channels and stagnant regions. The initial concentration of the single component 4-NP and 2,4-DNP solutions was $13 \mathrm{mg}$ $\mathrm{dm}^{-3}$. Series of experiments with $34,68,100$ and $200 \mathrm{~g}$ adsorbent in the column were performed. During the adsorption process samples were regularly taken at different bed depths, then filtered immediately and analyzed on spectrophotometer SPECORD UV VIS, Carl Zeiss Jena, at the corresponding wavelength.

The working temperature was $20 \pm 2^{\circ} \mathrm{C}$. The $\mathrm{pH}$ was measured on LHP 403T TACUSSEL $\mathrm{pH}-$ meter.

\section{RESULTS AND DISCUSSION}

\section{Adsorption equilibrium}

The sorption isotherms of 4-nitrophenol (4$\mathrm{NP})$ and 2,4-dinitrophenol (2,4-DNP) onto perfil were determined and are presented in Fig 1 . The equilibrium sorption data can be modelled by using the Langmuir equation:

$$
\frac{q_{e}}{q_{m}}=\frac{K_{L} C_{e}}{1+K_{L} C_{e}}
$$

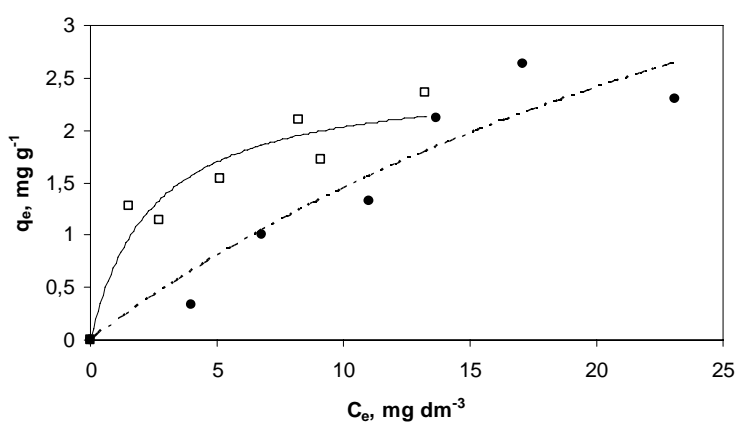

Fig. 1. Comparison of experimental and estimated data by Langmuir equilibrium isotherm System 2,4-DNP- perfil:

- experimental data $-\cdot-\cdot-\cdot$ theoretical curve System 4-NP- perfil:

experimental data theoretical curve

The values of Langmuir parameters are presented in Table 4.

Table 4

Parameters in the equilibrium isotherm for the investigated systems

\begin{tabular}{lccc}
\hline \hline System & \multicolumn{3}{c}{ Langmuir isotherm } \\
\cline { 2 - 4 } & $\begin{array}{c}K_{L} \\
\left(\mathrm{dm}^{3} / \mathrm{g}\right)\end{array}$ & $\begin{array}{c}q_{m} \\
(\mathrm{mg} / \mathrm{g})\end{array}$ & $r^{2}$ \\
\hline 4-NP-perfil & 0,4119 & 2,525 & 0,71161 \\
2,4-DNP-perfil & 0,02532 & 7,156 & 0,90553 \\
\hline \hline
\end{tabular}

The experimental equilibrium data for 4-NP and 2,4-DNP on the mineral material perfil were correlated with the Langmuir model using MatLab. The isotherms for both nitrophenols are smooth with a small slope, i.e. an initial steep stage and a horizontal plateau are absent. According to the results the mononitrophenol demonstrates greater affinity to perfil, as the experimentally calculated adsorption capacity for 4-NP is $2,525 \mathrm{mg} \mathrm{g}^{-1}$, while that for 2,4-DNP is $7,156 \mathrm{mg} \mathrm{g}^{-1}$. In general, the values of the isotherm constants obtained in a batch system are considerably higher than those obtained in a fixed bed. In a batch system the flow rate of the solution is zero, so the contact time between the sorbate solution and the sorbent approximates infinity. These experimental data are generally used in further studies concerning the dynamic sorption of solute in column studies for prediction of breakthrough curves. 


\section{Breakthrough dynamic}

The most important criterion in the design of fixed bed adsorption systems is the prediction of the column breakthrough of the shape of the adsorption wave front, which determines the operating life-span of the bed and the regeneration times. The experimental breakthrough curves for the systems 4-NP and 2,4-dinitrophenol 2,4-DNP onto perfil are given in Fig. 2 and Fig. 3, respectively.

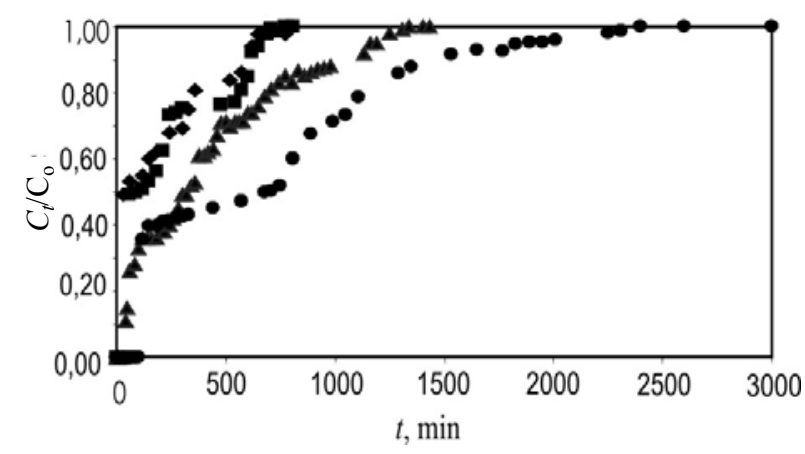

Fig. 2. Breakthrough curves for 4-Nitrophenol on perfil for

$$
\begin{gathered}
\text { four adsorbent mass } \\
\mathrm{Co}=13 \mathrm{mg} \mathrm{dm}{ }^{-3}, Q=113 \mathrm{~cm}^{3} \mathrm{~min}^{-1} ; d_{p}=1.5-3 \mathrm{~mm} \\
\bullet 34 \mathrm{~g} ; \quad 68 \mathrm{~g} ; \Delta 100 \mathrm{~g} ; \bullet 200 \mathrm{~g}
\end{gathered}
$$

At smaller amount of adsorbent the saturation rate is higher. The curves for 34 and $68 \mathrm{~g}$ of perfil are characterized with a steep initial stage, and they practically coincide, while those for 100 and $200 \mathrm{~g}$ sorbent are smoother. According to the experimental data the breakthrough time $\left(\right.$ at $\mathrm{C}_{\mathrm{b}} / \mathrm{C}_{\mathrm{o}}=$ 0.1 ) increases directly with the increase of sorbent mass and reaches about 90 min for the experiment with $200 \mathrm{~g}$ perfil.

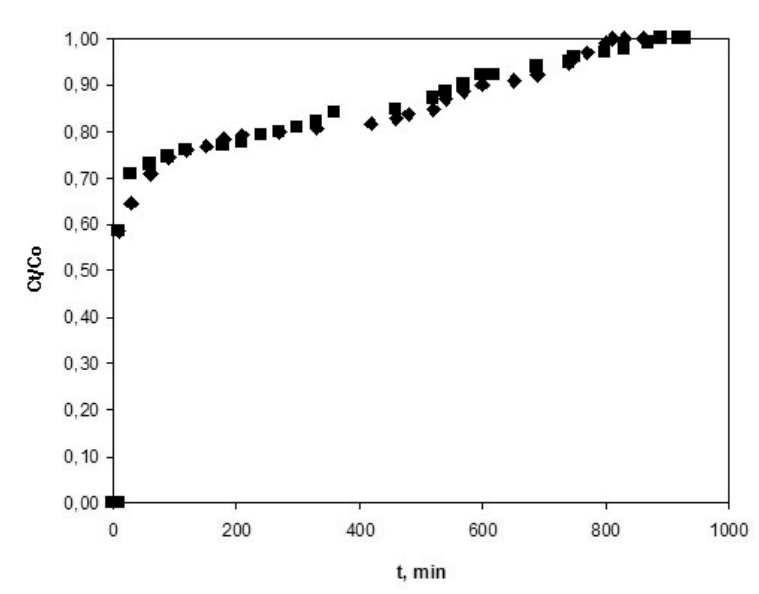

Fig. 3. Breakthrough curves for 2,4-Dinitrophenol on perfil for two adsorbent mass

$\mathrm{Co}=13 \mathrm{mg} \mathrm{dm}^{-3}, Q=113 \mathrm{~cm}^{3} \mathrm{~min}^{-1}, d_{p}=1.5-3 \mathrm{~mm}$
The difference in the chape of the breakthrough curves for 4-NP and 2,4-DNP are a reflection of the sorbate nature. Probably the greater 2,4DNP molecules induce a "molecular sieve" effect and block the pores entrances, thus the new dinitrophenol molecules meet a greater resistance and the saturation time is prolonged. Actually, the time necessary for the total saturation of the adsorbent bed is 750-800 min for 4-NP and 900-930 min for the experiments with $2,4-\mathrm{DNP}$.

\section{Model fitting of breakthrough curves}

The main purpose of this work was to perform parametric analysis of the breakthrough curves for the systems 4-NP and 2,4-dinitrophenol 2,4-DNP onto perfil using the proposed model [19] and prepared program [29]. The influence of the three major variables in the model, $k_{f}$, the external liquid film mass transfer coefficient, $D_{L}$, the axial dispersion coefficient, and $D_{s}$, the solid diffusion coefficient, on the breakthrough curves was investigated.

Axial dispersion is a function of physical factors like flow rate and particle size of the adsorbent, but is not dependent on the differences chemical properties of the solutes. The axial dispersion coefficient for the liquid flowing through fixed beds was obtained from the correlation equation Chung and Wen [30]:

$$
\frac{D_{L} \rho}{\mu}=\frac{\mathrm{Re}}{0,2+0,011 \mathrm{Re}^{0,48}}
$$

where $\operatorname{Re}=\frac{d v \rho}{\mu}$ is the Reynolds number.

Equation (24) is applicable in the Reynolds number range of $10^{-3}$ to $10^{3}$.

Many correlations were developed to express the Sherwood number as a function of the Reynolds number and Schmidt number, of which the following is used frequently and in the same time gives a satisfactory prediction of the individual liquid film mass transfer coefficient in column adsorption experiment [31]:

$$
S h=2+1,1 \operatorname{Re}^{06} S c^{1 / 3}
$$

where $S c=\frac{\mu}{\rho D_{m}}$ is the Schimdt number 
Equation (25) is applicable in the Reynolds number range of 3 to $10^{4}$. The values of molecular diffusivity, $D_{m}$ in the Sherwood number was estimated from the equation of Gilliland [32]:

$$
D_{m}=\frac{1.10^{-6}}{A \cdot B \sqrt{\mu_{B}} \cdot\left(\vartheta_{A}^{\frac{1}{3}}+\vartheta_{B} \frac{1}{3}\right)^{2}} \sqrt{\frac{1}{M_{A}}+\frac{1}{M_{B}}} .
$$

The ranges of values for the three variables in the model, the external liquid film mass transfer coefficient $\left(k_{f}\right)$, the axial dispersion coefficient $\left(D_{L}\right)$ and the solid diffusion coefficient $\left(D_{s}\right)$ are given below for the both systems and all investigated conditions:

$$
\begin{gathered}
D_{L}=1 \times 10^{-8} \text { to } 5 \times 10^{-8} \mathrm{~m}^{2} \mathrm{~s}^{-1} \\
k_{f}=1 \times 10^{-7} \text { to } 8 \times 10^{-7} \mathrm{~m} \mathrm{~s}^{-1} \\
D_{s},=0,9 \times 10^{-7} \text { to } 3,3 \times 10^{-7} \mathrm{~m}^{2} \mathrm{~s}^{-1}
\end{gathered}
$$

The shape of the breakthrough curves varied according to the values of each of these three parameters and their magnitudes. A sensitivity analysis was carried out by varying each of the parameters individually while maintaining the others constant.

\section{Effect of $D_{L}$}

The values of the axial dispersion did not have a significant influence on the shape of the breakthrough curves for both systems in all investigated conditions. The particular values of the axial dispersion coefficient were selected (Table 5) in the studies of the influence of the external liquid film mass transfer coefficient $\left(k_{f}\right)$ and the solid diffusion coefficient $\left(D_{s}\right)$ on the breakthrough curves shape.

\section{Effect of $k_{f}$}

The $k_{f}$ is an important controlling parameter in the sorption process. For fixed bed adsorption, film mass transfer would have a more pronounced effect than in batch adsorption. This is because of the presence of the boundary layer that would be prominent due to the nature of fixed bed adsorption, and thus would enhance the effect of the film mass transfer. Figs. 4 and 5 show the effect of $k_{f}$ to 4-NP/perfil at $6 \mathrm{~cm}$ and 2,4-dinitrophenol 2,4$\mathrm{DNP} /$ perfil systems at $2 \mathrm{~cm}$ bed height. The other conditions, particle diameter $3 \mathrm{~mm}$, initial concentration $13 \mathrm{mg} \mathrm{dm}{ }^{-3}$, flow rate $113 \mathrm{~cm}^{3} \mathrm{~min}^{-1}$, and temperature of $25^{\circ} \mathrm{C}$, were identical for both systems.
Careful consideration of Figures 4 and 5 indicates that a general conclusion regarding fitting the experimental data with theoretical model can not be made for the entire range of breakthrough curves. The same conclusion can be drawn for all investigated conditions for both systems. Presented in Table 5 are the values of the used parameters, namely the external mass transfer coefficient, the solid diffusion coefficient and the axial dispersion coefficient which give the best fit of the theoretical curves with the experimental data.

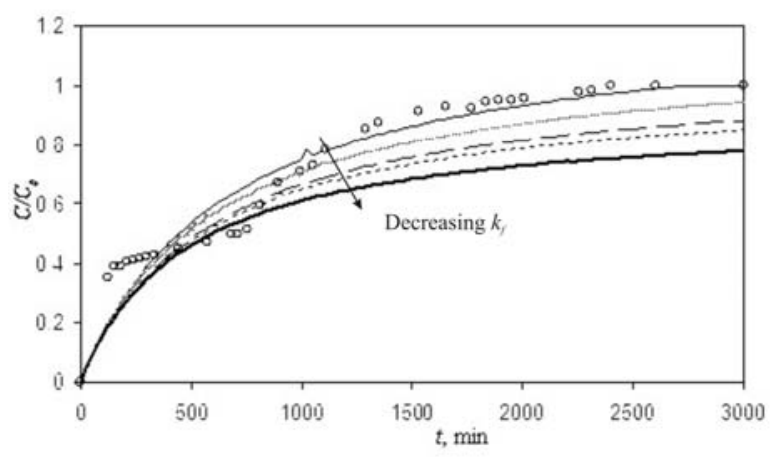

Fig. 4. Application of the model to 4-NP/ perfil systemexperimental and theoretical curves. $\mathrm{O}-$ experimental data;

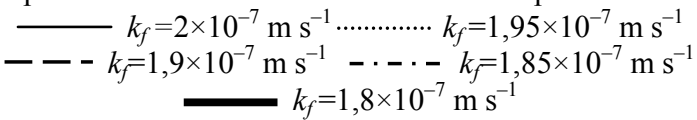

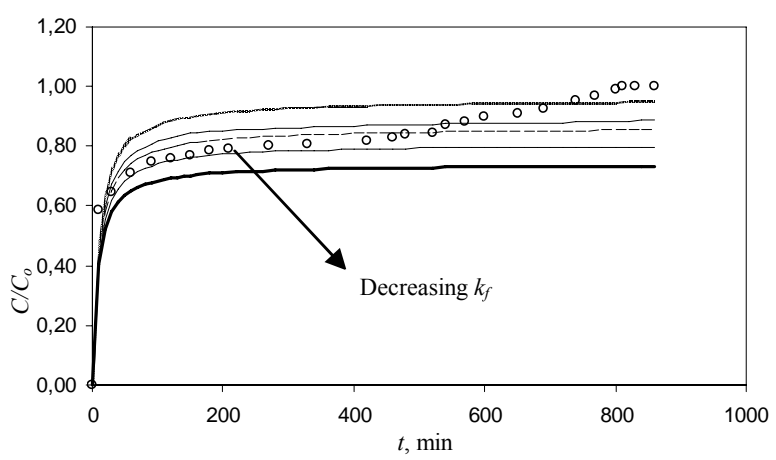

Fig. 5. Application of the model to 2,4-DNP/ perfil system, experimental and theoretical curves. $\mathrm{O}-$ experimental data; $-1 k_{f}=7,8 \times 10^{-7} \mathrm{~m} \mathrm{~s}^{-1} \ldots \ldots \ldots \ldots . . k_{f}=7,75 \times 10^{-7} \mathrm{~m} \mathrm{~s}^{-1}$
$---k_{f}=7,7 \times 10^{-7} \mathrm{~m} \mathrm{~s}^{-1}-\cdot-\cdot-k_{f}=7,654 \times 10^{-7} \mathrm{~m} \mathrm{~s}^{-1}$
$k_{f}=7,6 \times 10^{-7} \mathrm{~m} \mathrm{~s}^{-1}$

The values of $k_{f}$ showed that the mass transfer resistance is bigger in the system 4-NP/perfil than in the system 2,4-DNP/perfil for all investigated conditions. It was also found that the mass transfer coefficients estimated using Sherwood number (Eq. 25) are higher than those given from the fitting of the experimental curves with theoretical model. For example, the calculated $k_{f}$ is in the range of $2.75 \times 10^{-5}$ to $4,0 \times 10^{-5}$ while the experimental one is in the range of $1 \times 10^{-7}$ to $2 \times 10^{-7} \mathrm{~m} \mathrm{~s}^{-1}$ for the system 4-NP/perfil, implicating that the solid 
phase mass transfer resistance does exist and plays a certain role in the breakthrough curve.

\section{Effect of $D_{s}$}

Transitional pores (Table 2) are the inlet to the interior of adsorbent particles, and occupy most of the pore volume. Molecular transport in the these pores can be described by the solid diffusion mechanism, measured by $D_{s}$, the solid diffusivity. Its value largely depends on the surface properties of the adsorbents. Figs. 6 and 7 show the effect of $D_{s}$ to $4-\mathrm{NP} /$ perfil at $1 \mathrm{~cm}$, and 2,4dinitrophenol 2,4-DNP/ perfil systems at $3 \mathrm{~cm}$ bed height. The other conditions, particle diameter 3 $\mathrm{mm}$, initial concentration $13 \mathrm{mg} \mathrm{dm}{ }^{-3}$, flow rate $113 \mathrm{~cm}^{3} \mathrm{~min}^{-1}$, and temperature of $25^{\circ} \mathrm{C}$, were identical for both systems. For the present systems, the values of $D_{\mathrm{s}}$ are shown in Table 5 and compared to the 4-NP the values of $D_{s}$ are lower than those of 2,4-DNP.

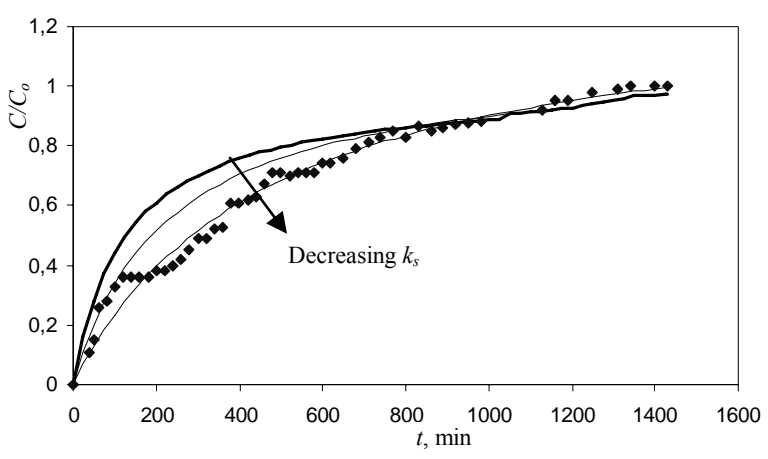

Fig. 6. Application of the model to 4-NP/ perfil system, experimental and theoretical curves

- experimental data; $-D_{s}=3,3 \times 10^{-8} \mathrm{~m}^{2} \mathrm{~s}^{-1}$; - - $D_{s}=3,25 \times 10^{-8} \mathrm{~m}^{2} \mathrm{~s}^{-1} ; \quad \mathrm{D}_{\mathrm{s}}=3,20 \times 10^{-8} \mathrm{~m}^{2} \mathrm{~s}^{-1}$

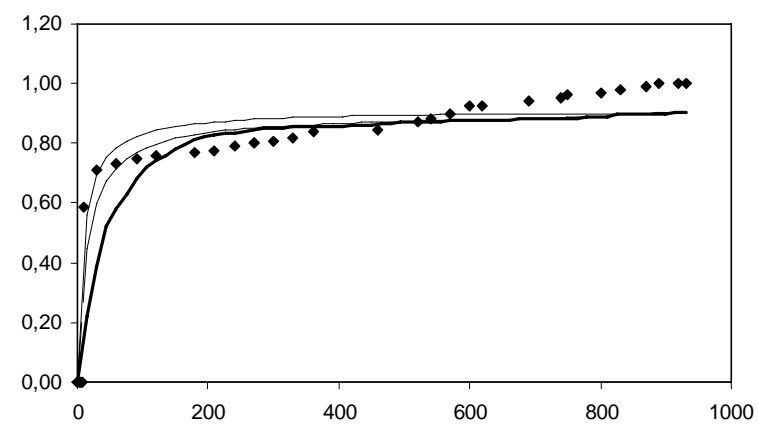

Fig. 7. Application of the model to 2,4-DNP/perfil system, experimental and theoretical curves

- experimental data; $-D_{s}=2,1 \times 10^{-7} \mathrm{~m}^{2} \mathrm{~s}^{-1}$. $--D_{s}=2,0 \times 10^{-7} \mathrm{~m}^{2} \mathrm{~s}^{-1} ; \longrightarrow D_{s}=1,90 \times 10^{-7} \mathrm{~m}^{2} \mathrm{~s}^{-1}$
The values of $D_{s}$ were obtained with the other two parameters $k_{f}$ and $D_{L}$ remaining constant. The final values of the investigated parameters which give the best fit with the experimental data are presented in Table 5.

\section{Table 5}

Experimental values of the external liquid film mass transfer coefficient, the axial dispersion coefficient, and solid diffusion coefficient

\begin{tabular}{|c|c|c|c|c|c|c|}
\hline \multirow{2}{*}{$\begin{array}{l}\text { System } \\
\text { Bed depth, } \\
\mathrm{cm} / \text { (Adsorbent } \\
\text { mass, g) }\end{array}$} & \multicolumn{3}{|c|}{ 4-NP - perfil } & \multicolumn{3}{|c|}{ 2,4 DNP - perfil } \\
\hline & $\begin{array}{c}k_{f} 10^{7} \\
\mathrm{~ms}^{-1}\end{array}$ & $\begin{array}{l}\mathrm{D}_{\mathrm{s}} 10^{7} \\
\mathrm{~m}^{2} \mathrm{~s}^{-1}\end{array}$ & $\begin{array}{c}\mathrm{D}_{\mathrm{L}} 10^{8} \\
\mathrm{~ms}^{-1}\end{array}$ & $\begin{array}{c}k_{f} 10^{7} \\
\mathrm{~ms}^{-1}\end{array}$ & $\begin{array}{l}D_{s} 10^{7} \\
\mathrm{~m}^{2} \mathrm{~s}^{-1}\end{array}$ & $\begin{array}{r}D_{L} 10^{8} \\
\mathrm{~ms}^{-1}\end{array}$ \\
\hline $1 /(34)$ & 1,15 & 0,90 & 1,80 & 7,60 & 2,20 & 4,30 \\
\hline $2 /(68)$ & 1,30 & 1,15 & 2,10 & 7,80 & 3,30 & 5,60 \\
\hline $3 /(100)$ & 1,40 & 1,80 & 2,20 & & & \\
\hline $6 /(200)$ & 2,00 & 2,70 & 2,30 & & & \\
\hline
\end{tabular}

Biot number, in the model measures the ratio of internal to external mass transfer resistances within the column. An increased $B i$ value would indicate an increase of intraparticle diffusion resistance. Therefore, Bi would approach infinity for an intraparticle diffusion controlled process, and approach zero for a film diffusion controlled process. The $B i$ values for the systems under investigation were very small and they approach zero. It is observed that Bi slowly decreased with the increase of bed depth. As the bed depth increased, film resistance increased or intraparticle diffusion resistance decreased.

\section{CONCLUSION}

The adsorption of 4-nitrophenol and 2,4- dinitrophenol onto perfil in a fixed bed column was studied. The theoretical solid diffusion control (SDC) model describing single solute adsorption in a fixed bed based on the Linear Driving Force (LDF) kinetic model was successfully applied to the investigated systems. However, some deviations were found between the predicted and the experimental data which reflect the fact that the assumptions of the model were not quite fulfilled for these experiments. This refers especially to the assumption of a constant solid diffusion coefficient. It is thus necessary to adjust the values of the solid diffusion coefficient, the axial dispersion 
coefficient and the external mass transfer coefficient to obtain satisfactory agreement between the simulated and the experimental breakthrough curves.

\section{NOTATION}

$$
\begin{aligned}
& \text { A } \quad-1.23 \text { for 4-NP (Eq.26) } \\
& a \text { - surface area, } \mathrm{m}^{2} \text {; } \\
& B \quad-4.7 \text { for water (Eq.26) } \\
& B i \text { - Biot number } \\
& C_{b} \text { - bulk phase dye concentration, } \mathrm{mg} \mathrm{dm}^{-3} \\
& C_{e} \text { - equilibrium concentration, } \mathrm{mg} \mathrm{dm}^{-3} \\
& C_{i n} \text { - inlet concentration, } \mathrm{mg} \mathrm{dm}^{-3} \\
& C_{o} \text { - initial concentration, } \mathrm{mg} \mathrm{dm}^{-3} \\
& C_{s} \quad \text { - liquid phase concentration in equilibrium } \\
& \text { with } q_{s} \text { on the surface, } \mathrm{mg} \mathrm{dm}^{-3} \\
& \bar{C} \text { - average liquid phase concentration, } \mathrm{mg} \mathrm{dm}^{-3} \\
& d \text { - inside diameter of the column, } \mathrm{m} \\
& d_{p} \quad \text { - particle diameter, } \mathrm{m} \\
& D_{L} \quad \text { - axial dispersion coefficient, } \mathrm{m}^{2} \mathrm{~s}^{-1} \\
& D_{m}-\text { molecular diffusivity, } \mathrm{m}^{2} \mathrm{~s}^{-1} \\
& D_{\mathrm{s}}-\text { solid diffusion coefficient, } \mathrm{m}^{2} \mathrm{~s}^{-1} \\
& k_{f} \quad \text { - mass transfer coefficient, } \mathrm{m} \mathrm{s}^{-1} \\
& K_{L} \text { - Langmuir isotherm parameter, } \mathrm{dm}^{-3} \mathrm{mg}^{-1} \\
& L \quad \text { - column length, } \mathrm{m} \\
& M \text { - uptake rate of adsorption, } \mathrm{mg} \mathrm{s}^{-1} \mathrm{dm}^{-3} \\
& M_{A} \text { - molecular mass of 4-NP, } \mathrm{kg} \mathrm{kmol}^{-1} \\
& M_{B} \text { - molecular mass of water, } \mathrm{kg} \mathrm{kmol}^{-1} \\
& P e \quad \text { - Peclet number } \\
& \bar{q} \quad \text { - average adsorbed phase dye concentration, } \\
& \mathrm{mg} \mathrm{g}^{-1} \\
& q_{o} \quad \text { - initial concentration in solid phase, } \mathrm{mg} \mathrm{g}^{-1} \\
& q_{s} \text { - concentration on the surface of the pellets, } \\
& \mathrm{mg} \mathrm{g}^{-1} \\
& q_{m} \quad \text { - Langmuir isotherm parameter, } \mathrm{mg} \mathrm{g}^{-1} \\
& Q \text { - flowrate, } \mathrm{cm}^{3} \mathrm{~min}^{-1} \\
& R_{p} \quad \text { - radius of the adsorbent pellets, } \mathrm{m} \\
& r \quad \text {-linear correlation coefficient } \\
& \text { Re - Reynolds number } \\
& \text { Sc - Schmidt number } \\
& \text { Sh - Sherwood number } \\
& t \text { - time, } \mathrm{s} \\
& v-\text { interstitial velocity, } \mathrm{m} \mathrm{s}^{-1} \\
& V \quad \text { - volume, } \mathrm{dm}^{3} \\
& Y \text { - dimensionless axial coordinate }
\end{aligned}
$$

$$
\begin{array}{ll}
Z & \text { - axial coordinate, } \mathrm{m} \\
\mathrm{W} & \text { - adsorbent mass, } \mathrm{g}
\end{array}
$$

\section{Greek letters:}

$\varepsilon \quad-$ bed porosity

$\varepsilon_{\mathrm{p}} \quad$ - porosity of an adsorbent pellet

$\mu_{B} \quad-$ water viscosity at $20^{\circ} \mathrm{C}, \mathrm{Pa} \mathrm{s}^{-1}$;

$\rho \quad-$ liquid density, $\mathrm{g} \mathrm{cm}^{-3}$

$\theta$ - dimensionless time variable

$v_{A} \quad$ - molecular volume of 4-NP, $\mathrm{cm}^{3} \mathrm{~g}^{-1} \mathrm{~mol}^{-1}$

$v_{B} \quad-$ molecular volume of water, $\mathrm{cm}^{3} \mathrm{~g}^{-1} \mathrm{~mol}^{-1}$ );

Acknowledgments: The authors acknowledge gratefully the financial support from the Ministry of Education and Science of R. Macedonia and the Ministry of Education and Science of Bulgaria (contract BM-8/05).

\section{REFERENCES}

[1] Z. Yaneva, B. Koumanova, Comparative modeling of mono- and dinitrophenols sorption on yellow bentonite from aqueous solutions, J. Colloid Interface Sci., 293, 303-311 (2006).

[2] M. Akcay, G. Akcay, The removal of phenolic compounds from aqueous solutions by organophilic bentonite, $J$. Hazard. Mater., B113, 1-3, 189-193 (2004).

[3] R. S. Juang, S. H. Lin, K. H. Tsao, Sorption of phenols from water in column systems using surfactant modified montmorillonite, J. Colloid Interface Sci., 269, 46-52 (2004).

[4] S. Yapar, M. Yilmaz, Removal of phenol by using montmorillonite, clinoptilolite and hydrotalcite, Adsorption, 10, 287-298 (2004).

[5] B. Koumanova, P. Peeva, Adsorption of p-chlorophenol from aqueous solutions on bentonite and perlite, J. Hazard. Mater., A90, 229-234 (2002).

[6] T. Sismanoglu, S. Pura, Adsorption of aqueous nitrophenols on clinoptilolite, Colloids and Surfaces A: Physicochemical and Engineering Aspects, 180, 1-2, 1-6 (2001).

[7] I. Uzun, F. Guzel, Rate studies on the adsorption of some dyestuffs and p-nitrophenol by chitosan and monocarboxymethylated(mcm)-chitosan from aqueous solution, $J$. Hazard. Mater., B 118, 141-154 (2005).

[8] I. Uzun, F. Guzel, External mass transfer studies during the adsorptions of some dyestuffs and p-nitrophenol onto chitosan from aqueous solution, Turk. J. Chem., 28, 731740 (2004).

[9] W. S. W. Ngah, S. Fatinathan, Chitosan flakes and chitosan-GLA beads for adsorption of $\mathrm{p}$-nitrophenol in aqueous solution, Colloids and Surfaces A: Physicochemical and Engineering Aspects, 277, 1-3, 214-222 (2006).

[10] K. Gupta, I. Ali, Removal of 2,4-dinitrophenol from wastewater by adsorption technology: a batch and column study, Int. J. Environ. Pollut., 27, 1/2/3, 104-120 (2006). 
[11] S. J. Allen, B. Koumanova, Z. Kircheva, S. Nenkova, Adsorption of 2-nitrophenol by Technical Hydrolysis Lignin: Kinetics, Mass Transfer and Equilibrium Studies, Ind. Eng. Chem. Res., 44, 2281-2287 (2005).

[12] B. Koumanova, P. Peeva, S. J. Allen, K. A. Gallegher, M. G. Healy, Biosorption from aqueous solutions by eggshell membranes and Rhizopus oryzae: equilibrium and kinetic studies, J. Chem. Technol. Biotechnol., 77, 539-545 (2002).

[13] G. McKay, J. F. Porter, G. R. Prasad, The removal of dye colours from aqueous solutions by adsorption on low-cost materials, Water Air Soil Pollut., 114, 423-438 (1999).

[14] Z. Kircheva, G. Oltean, D. Covaciu, B. Koumanova, M. Zitaru, Equilibrium study of 4-nitrophenol adsorption on natural materials from aqueous solutions, J. Univ. Chem. Technol. Met. (Sofia), 39, 3, 343-350 (2004).

[15] R. C. Martinez, M. S. Rios, V. M. Miranda, R. A. Cuevas, Sorption behavior of 4-chlorophenol from aqueous solutions by a surfactant-modified zeolitic rock in batch and fixed bed systems, Water Air Soil Pollut, 183, 85-94 (2007).

[16] B. C. Pan, F. W. Meng, X. Q. Chen, B. J. Pan, X. T. Li, W. M. Zhang, X. Zhang, J. L. Chen, Q. X. Zhang, Y. Sun, Application of an effective method in predicting breakthrough curves in fixed-bed adsorption onto resin adsorbent, J.Hazard. Mater., 124, 1-3, 74-80 (2005).

[17] Y. Fu, T. Viraraghavan, Column studies for biosorption of dyes from aqueous solutions on immobilized Aspergillus niger fungal biomass, Water $S A, 29,4,465-472$ (2003).

[18] R. Han, Y. Wang, W. Yu, W. Zou, J. Shi, H. Liu, Biosorption of methylene blue from aqueous solution by rice husk in a fixed-bed column, J. Hazard. Mater., 141, 3, 713-718 (2007).

[19] L. Markovska, V. Meshko, V. Noveski, M. Marinkovski, Solid diffusion control of the adsorption of basic dyes onto granular activated carbon and natural zeolite in fixed-bed columns, J. Serb. Chem. Soc., 66, 7, 463-475 (2001).

[20] M. Y. Teng, S. H. Lin, Removal of methyl orange dye from water onto raw and acid-activated montmorillonite in fixed beds, Desalination, 201, 71-81 (2006).
[21] O. Hamdaou, Dynamic sorption of methylene blue by cedar sawdust and crushed brick in fixed bed columns, $J$. Hazard. Mater., B138, 293-303 (2006).

[22] M. A. Cremasco, R. Guirardello, N. -H.L. Wang, Adsorption of aromatic amino acids in a fixed bed column, Braz. J. Chem. Eng., 20, 3, 327-334 (2003).

[23] S. H. Lin, Ch. S. Wang, Treatment of high-strength phenolic wastewater by a new two-step method, J. Hazard. Mater. B90, 205-216 (2002).

[24] G. Vazquez, R. Alonso, S. Freire, J. G. Alvarez, G. Antorrena, Uptake of phenol from aqueous solutions by adsorption in a Pinus Pinaster bark packed bed, J. Hazard. Mater., B133, 61-67 (2006).

[25] A. Wolborska, P. Pustelnik, A simplified method for determination of the break-through time of an adsorbent layer, Wat. Res., 30, 11, 26-43-2650 (1996,).

[26] S. Y. Quek, B. Al-Duri, Application of film-pore diffusion model for the adsorption of metal ions on coir in a fixed-bed column, Chem. Eng. Process., 46, 477-485 (2007).

[27] C. Yao, C. Tien, Approximations of the uptake rate of spherical adsorbent pellets and their application to batch adsorption calculations, Chem. Eng. Sci. 48 (1), 187-108 (1993).

[28] C. Yao, C. Tien Approximate solution of intraparticle diffusion equations and their application to continuousflow stirred tank and fixed bed adsorption calculations Sep. Technol. 4, 67-80 (1994).

[29] Liljana Markovska and Vera Meshko, Dynamic simulation of the processes, University "SS. Cyril and Methodius", Skopje 2002 (in Macedonian).

[30] R-T. Huang, T-L. Chen, H-S. Weng, Binary adsorption in a fixed bed column packed with an ion-exchange resin, Sep. Sci. Tech., 30 (13), 2731-2746 (1995).

[31] D. O. Cooney, Adsorption design for wastewater treatment, Lewis Publishers, Boca Raton, 1999.

[32] К. Ф. Павлов, П. Г. Романков, А. А. Носков, Примери и задачи по прочеси и апарати в химическата промишленост, Техника, София, 1990 (in Bulgarian). 